\title{
Internet culture--a new way for ideological and political education of university students
}

\author{
Mao Yang \\ University of Electronic Science and Technology \\ of China, Chengdu, Sichuan 610054
}

Abstract - At current internet has been an indispensable part in university students' life. Internet culture changes and influences contemporary university students' ideology, behavior pattern and moral concept and has a far-reaching influence on the ideological and political education of university students, and internet cultural environment has also been an important component of university students' ideological and political education environment. Compared with traditional campus culture, internet culture has its own features. Although it has its own limitation during the ideological and political education process of university students, it is also a new groping way.

Key words-Internet culture, Ideological and political education, New way

\section{INTRODUCTION}

\section{Definition of internet culture}

Internet culture is the material and spiritual activities which come into being based on information, network technique and network platform and resources etc and the achievements they bring about. Internet culture can be divided into the internet culture in a narrow sense and the internet culture in a broad sense. The internet culture in a narrow sense refers to a

\author{
Yan Wang \\ University of Electronic Science and Technology \\ of China, Chengdu, Sichuan 610054
}

series of cultural activities carried out on the basis of the internet platform; the internet culture in a broad sense is the extension and development of traditional culture under new circumstances and conditions; it is people's reflection and projection of real life in the internet world; it is the sum total of human beings' manifestation in thinking, psychology, language, morality and behavior which relies on real life but is different from the reality; it is a part of modern people's cultural activities.

\section{Features of internet culture}

(1) Openness and popularity

The characteristic that internet culture is based on network technique determines internet culture is featured by openness. The overall virtual internet has no specific restrictions and under normal circumstances it will be wide-open and information sharing, which is a fundamental purpose of internet culture and does help to knowledge accumulation and the information sharing of individual development. So people's individual development and event march will not be subject to geographical limitations and timeliness any more. Instead, individual perception and practical activities are extended to the entire internet population and all parts of the world which possess internet, thus affecting the entire human society, and in turn influencing and boosting the promotion of the need of individual development and 
individuation in the entire human society.

The openness of internet culture also determines the strong popularity of internet culture which is genuine "grass-root culture". Such kind of explosive interpersonal communication characteristic leads to internet culture's lack of centrality.

(2) Virtual interaction and compensatory property

The subject on internet is different from the subject in reality and its existence is completely virtual. It may correspond to a certain person, organization or even a subject which cannot be concrete in real life. In cyber world all subjects can have open bilateral communication in no need of a real identity. That is the virtual interaction of internet. It is due to the virtual interaction of internet that people can cast traditional rules and requirements aside, express them boldly, show their advantages, weaken their own weaknesses, realize their value and satisfy themselves through communication and assistance, and even achieve the power and influence which are hard to be obtained in actual life. Thus another important feature of internet culture comes into being. That is the "compensatory property".

(3) Timeliness, variability and extremity The clustering of the cultural subject and the informatization of the cultural carrier determine internet culture has timeliness and variability at outside. Internet culture also has extremity. As mentioned before, internet is featured by openness and timeliness. A huge number of people can enter into a discussion topic within a moment. However, most people have a herd mentality which will result in that users' original opinions, no matter what kind they are, are likely to be amplified during group discussion and anxious for more prominence. Under constant expression and strengthening, most of the original views will be driven to an extreme. The extremity of internet culture can maximize both "goodness" and "badness".

\section{Network cultural environment is an important component of university students' ideological and political education environment.}

With the rapid development of digital information age, internet has been an indispensable part of people's life in modern society. The function of internet is expanding and its seepage force is deepening. For today's universities and colleges, internet culture is a necessary medium and area for the ideological and political education of universities. The internet culture in universities and colleges has diversified forms and functions including thought guidance, public opinion guidance and atmosphere creation etc.

\section{Internet culture is a part of modern campus culture.}

Internet culture is based on campus culture and is the product of the network virtualization of campus culture. Meanwhile with the support of internet, internet culture breaks the time and spacial limits of campus culture and greatly extends the timeliness and effectiveness of campus culture. Take University of Electronic Science and Technology of China as an example. At the early period when internet was spread to the university, students established a campus BBS at the first time which are called "Infinite Dormitory Power" and "Network Love Story" respectively. The former is based on students' dormitories and the latter has all the students of the university as the subject, and thus an unique BBS culture comes into being. A survey conducted by the school in November 2015 shows that $83.59 \%$ students keep an eye on hot 
domestic and foreign news and emergencies on the internet, and they will discuss with people around them. That means students narrow the space with social contract via internet.

\section{Network culture environment possesses high involvement.}

With the progress of network technology and the popularization of internet, network culture environment also changes greatly, and thus affects ideological and political education. Traditional ideological and political education stays at interpersonal face-to-face communication or communication by telephone or mail. It gradually steps toward the communication via internet. Influence the object of education with new means and "we media"; university students' study and life are enriched and colorful. As for the ideological and political education work of universities and colleges, the means and methods are innovated and the working idea and space are expanded, which facilitates the new improvement and development of the object, means, psychology and measures of ideological and political education.

\section{Network culture education is a new way for the ideological and political education of university students.}

With the further deepening of the influence of internet on individuals' lifestyle, network technology has extended to practical range of services which combines applications like cloud computing, internet of things and big data from personalized applications based on information acquisition and communication of entertainment needs. The internet culture arising on such technological basis provides university students not only a new way of cultural transmission and communication but also a new educational method, which affects and changes university students' way of thinking and behavior pattern unconsciously. Although internet culture has its own limitations to some extent, it is really a new way for the ideological and political education of university students.

\section{Students are more active on internet and} internet culture gradually becomes the major ground for the ideological and political education of university students.

Researches have shown that at current internet has been the chief channel for university students to get information while mobile phone is students' first terminal choice. Over $80 \%$ students' net age is longer than 5 years and they form the habit of surfing the internet regularly; they are so-called senior netizens. In 2015 the Communist Youth League Beijing municipal Party committee conducted a survey together with a research group. The survey report reveals that for the students of the universities in Beijing, $74.67 \%$ of them use most of their spare time to surf the internet; the proportion of the students who use over two hours to surf the internet is $70.3 \%$, among which the proportion of the students who use about three hours to surf the internet is $17.9 \%$; students use about four hours to surf the internet occupy 10.7\%; students use five hours or more to surf the internet occupy $13.1 \%$. In the face of such an active university student group on internet, future direction of development is to carry out ideological and political education via internet culture and internet culture also becomes the major ground for the ideological and political education of university students.

\section{The carriers of the ideological and political} education of university students under internet culture are diversified.

Generally speaking students have more energy and time; they have a strong demand for exciting games and information exchange and 
also take delight in trying new things. With the maturity of "we media" technology, various interesting app and games satisfy their needs and offer them a platform and vent for their desire, and meanwhile make students become important information producers, participants and transmitter. They get into the habit of taking pictures, writing, sharing and transmitting information at any time. A lot of platforms and carriers based on students' varied interests, hobbies and regions come into being. According to the understanding of the students of the school where the author belongs, the first thing students do on internet is to watch movies and play games; the second is to use social software including QQ, microblog and wechat etc; both aspects account for nearly $2 / 3$. The proportion of the students who use the internet to retrieve and browse news and acquire learning materials is over $50 \%$; more than $1 / 3$ of the students will shop online.

3. The coverage of the ideological and political education of university students is wider and the timeliness is stronger under internet culture.

At current with the progress and development of network technology, traditional teaching mode has changed to a new teaching mode supported by technologies like internet, videos and interactive platforms; traditional ideological and political education is also enlarged to cover a wider space from classrooms and second classrooms, and the time thread is shortened.

\section{IV .Conclusion}

A questionnaire survey on the ideological and political education of university students conducted by the School of Physical Electronics in November 2015 demonstrates that $74.06 \%$ students think they will be affected by internet expressions and opinions to some extent, but they will choose to accept a few based on their own experience; $10.85 \%$ students think they are greatly influenced. So universities can combine traditional ideological and political education and online ideological and political education according to the features of internet culture, cover all students through ways which can satisfy students' needs and ideological characteristics, lead students to participate and innovate creatively, provide diversified platform of participation, highlight the ideological level, the specialty, the interaction and the originality and realize all-round education.

\section{Acknowledgements}

Topic: A research of the influence of a changing network environment on the ideological and political education of university students A fundamental research funding project of 2015 Fundamental Research Funds for the Central Universities No.: ZYGX2014J120

\section{Reference}

[1] Zhichao Chen, Qianshen Wang, Use advanced network culture to guide the ideological and political work of university students [J], Journal of Ideological Theoretical Education, vol. 03, 2012.

[2] Xiaorong Shen, Huaijie Li, An exploration and analysis of the network culture construction of universities and colleges and the ideological and political education of university students [J], Studies in Ideological Education, vol. 10, 2011.

[3] Xiaobai Sheng, Basic features of network culture [N], Guangming Daily, January 20, 2008 (006).

[4] Bo Zhou, Xiaonian Liu, Cultivate high-quality "digital citizens"--a survey report on strengthening university students' internet literacy construction [N], April 30, 
2015 (005).

[5] Baocheng Zhang, A study of the current situation of internet management and countermeasures in China [D], Inner Mongolia: Inner Mongolia Normal University, pp. 1-29, 2013.

[6] A survey of 800,000 students' characteristics: surfing the internet and sleeping become major recreation $[\mathrm{N}]$, China Youth News, May 4, 2015.

[7] A questionnaire survey of the ideological and political education of university students 